\title{
Perlukah Sumut Dimekarkan?
}

\author{
Oleh : Pardomuan Gultom
}

Pada 2 Mei 2011 yang lalu Panitia Khusus (Pansus) Pemekaran Propinsi Sumatera Utara - yang dibentuk oleh DPRD Propinsi Sumatera Utara - membacakan laporan Pansus Pemekaran atas kajian, hasil studi banding (Propinsi Kepulauan Riau dan Propinsi Bangka Belitung), hasil kunjungan kerja ke daerah, dan aspirasi sejumlah kepala daerah, pimpinan DPRD Kabupaten/Kota, serta ormas terhadap usulan daerah yang akan dimekarkan.

Agenda pembacaan laporan Pansus Pemekaran Rapat paripurna DPRD Propinsi Sumatera Utara sempat tertunda dari yang dijadwalkan pada tanggal 25 April 2011. Laporan tersebut mencakup usulan 3 (tiga) daerah pemekaran, yakni: Propinsi Sumatera Tenggara, Propinsi Kepulauan Nias, dan Propinsi Tapanuli. Keterlambatan rapat paripurna DPRD Propinsi Sumatera Utara dengan agenda pembacaan laporan Pansus Pemekaran disebabkan belum maksimalnya laporan pansus dan juga perbedaan pendapat mengenai materi laporan pansus (Harian Seputar Indonesia, 03/05). Dan wacana ini menjadi perhelatan politik baru di Sumatera Utara pasca 'tragedi Protap' (baca: Provinsi Tapanuli).

Yang perlu dikaji disini adalah bagaimana perkembangan dalam pengusulan pembentukan Provinsi Sumatera Tenggara dan Provinsi Nias; dan untuk kasus tertentu, seperti usulan pembentukan Provinsi Tapanuli, apa perbedaan antara masa sebelum 'tragedi Protap' dan pasca tragedi tersebut serta seberapa besar peluangnya.

Untuk mengetahui prosesnya, maka yang menjadi landasan berpikir untuk menganalisa situasi yang berkembang dalam upaya pemekaran Provinsi Sumatera Utara, yakni dasar konstitusi yang menjadi landasan sistematika bagi pembentukan daerah otonom baru dan respon kebijakan. Dasar konstitusi maksudnya adalah aturan hukum (rule of law) dan aturan main (rule of game) yang diatur dalam Undang-Undang No. 32 Tahun 2004 tentang Pemerintahan Daerah dan Peraturan Pemerintah No. 78 Tahun 2007 tentang Tata Cara Pembentukan, Penghapusan, dan Penggabungan Daerah. dan respon kebijakan dimaksudkan pada proses politik yang dilalui dalam upaya pembentukan daerah otonom baru.

Sesuai ketentuan yang diatur dalam UU No. 32 Tahun 2004 dan PP No. 78 Tahun 2007, maka daerah yang mengusulkan pembentukan daerah otonom baru (provinsi atau kabupaten/kota) diwajibkan memenuhi 3 (tiga) syarat, yaitu: syarat administratif, syarat teknis, dan syarat fisik kewilayahan.

\section{Persyaratan}

Isu pemekaran atau pembentukan daerah otonom baru bukanlah agenda politik yang baru di Sumatera Utara. Dalam kurun waktu satu dekade terakhir (sejak 1999 hingga 2009), Sumatera Utara telah memekarkan 14 kabupaten/kota (lihat Daftar Daerah Otonom Baru (DOB) Pemekaran (1999 - 2009) oleh KPPOD). Pada tahun 2001, Kota Padang Sidempuan - melalui UU No. 4 Tahun 2001 - telah dimekarkan dari Kabupaten Tapanuli Selatan. Tahun 2003, ada 5 (lima) daerah otonomi baru, yakni: Kabupaten Pakpak Bharat, Kabupaten Nias Selatan, Kabupaten Humbang Hasundutan (UU No. 9 Tahun 2003); Kabupaten Serdang Bedagai dan Kabupaten Samosir (UU No. 36 Tahun 2003). Tahun 2007, ada 3 (tiga) daerah otonomi baru, yakni: Kabupaten Batubara (UU No. 5 Tahun 2007), 
Kabupaten Padang Lawas Utara (UU No. 37 Tahun 2007), dan Kabupaten Padang Lawas (UU No. 38 Tahun 2007). Tahun 2008, ada 5 (lima) daerah otonom baru, yakni: Kabupaten Labuhan Batu Utara (UU No. 23 Tahun 2008), Kabupaten Labuhan Batu Selatan (UU No. 22 Tahun 2008), Kabupaten Nias Barat (UU No. 46 Tahun 2008), Kabupaten Nias Utara (UU No. 45 Tahun 2008), dan Kota Gunung Sitoli (UU No. 47 Tahun 2008).

Kehadiran 14 kabupaten/kota yang telah dimekarkan ternyata berpeluang dalam membentuk provinsi baru. UU No. 32 Tahun 2004 telah memberi ruang bagi setiap kabupaten/kota untuk membentuk provinsi baru sesuai dengan ketentuan yang diatur dalam PP No. 78 Tahun 2007. Peluang tersebut jadi momentum untuk memekaran Provinsi Sumatera Utara dalam 3 (tiga) usulan provinsi, yakni: Propinsi Sumatera Tenggara (Kabupaten Padang Lawas, Kabupaten Padang Lawas Utara, Kota Padang Sidempuan, Kabupaten Mandailing Natal, dan Kabupaten Tapanuli Selatan), Propinsi Kepulauan Nias (Kabupaten Nias, Kabupaten Nias Utara, Kabupaten Nias Barat, Kabupaten Nias Selatan, dan Kota Gunung Sitoli), dan Propinsi Tapanuli (Kabupaten Tapanuli Utara, Kabupaten Toba Samosir, Kabupaten Humbang Hasundutan, dan Kabupaten Samosir).

Jika merujuk pada UU No. 32 Tahun 2004 Pasal 5 angka (5) dan PP No. 78 Tahun 2007 Pasal 8 huruf a, maka usulan pembentukan provinsi yang dianggap layak sesuai syarat fisik kewilayahan - selain syarat administratif dan syarat teknis - adalah Propinsi Sumatera Tenggara dan Propinsi Kepulauan Nias. Terlepas dari segala bentuk polemik yang pernah terjadi dalam upaya mengusung pembentukan Propinsi Tapanuli, ternyata usulan pembentukan Propinsi Tapanuli tidak mampu memenuhi syarat fisik kewilayahan karena hanya diusung oleh 4 (empat) kabupaten. Hal ini disebabkan oleh berkurangnya dukungan kabupaten/kota lain yang sebelumnya memberikan dukungan karena sikap yang tidak elegan dalam proses penyampaian aspirasi.

Selain persyaratan fisik kewilayahan yang dibutuhkan dalam pembentukan provinsi baru, dua syarat lainnya - administratif dan teknis - penting untuk disimak. Syarat administrasi meliputi 5 (lima) tahapan, yakni: (1) Keputusan masing-masing DPRD kabupaten/kota yang akan menjadi cakupan wilayah calon provinsi berdasarkan hasil rapat paripurna; (2) Keputusan bupati/walikota yang ditetapkan dalam keputusan bersama bupati/walikota wilayah calon provinsi tentang persetujuan pembentukan calon provinsi; (3) Keputusan DPRD provinsi induk tentang persetujuan pembentukan calon provinsi berdasarkan hasil Rapat Paripurna - yang berdasarkan aspirasi sebagian besar masyarakat setempat yang dituangkan dalam keputusan DPRD kabupaten/kota yang akan menjadi cakupan wilayah calon provinsi; (4) Keputusan gubernur tentang persetujuan pembentukan calon provinsi; dan (5) Rekomendasi menteri (PP No. 78 Tahun 2007, Pasal 5 Ayat (1) huruf (a), (b), (c), (d), (e) dan Ayat (4) ).

Syarat ketiga adalah syarat teknis yang meliputi faktor kemampuan ekonomi, potensi daerah, sosial budaya, sosial politik, kependudukan, luas daerah, pertahanan, keamanan, kemampuan keuangan, tingkat kesejahteraan masyarakat, dan rentang kendali penyelenggaraan pemerintahan daerah - yang dinilai berdasarkan hasil kajian daerah terhadap indikator (PP No. 78 Tahun 2007 Pasal 6 Ayat (1).

Untuk mengetahui lebih jauh proses penyelenggaraan kebijakan di bidang pembentukan daerah otonom baru, khususnya pemekaran di Provinsi Sumatera Utara, dapat kita perhatikan dari proses yang telah berjalan, baik dari sisi lokalitas, seperti: aspirasi publik, kemauan politik pemerintah daerah dan DPRD kabupaten/kota, aspek persyaratan, maupun respon kebijakan pemerintah pusat. 


\section{Pasang Surut}

Dalam perjalanannya, sejarah pembentukan Provinsi Tapanuli bisa menjadi sebagai bahan pembelajaran dalam upaya pembentukan provinsi baru lainnya. Artinya, dinamika politik pembentukan Provinsi Tapanuli mengalami perubahan dalam bentuk dukungan kabupaten/kota, metode artikulasi kepentingan, dan problem elitisme aktor-aktor pengusungnya.

Dari segi mobilisasi dukungan, ada 3 (tiga) fase yang telah dilalui dalam upaya pembentukan Provinsi Tapanuli, yakni: pertama, fase embrio (2002-2004), yang diawali dengan usulan 4 (empat) kabupaten/kota untuk membentuk Provinsi Tapanuli, yang terdiri dari Kabupaten Tapanuli Utara, Kabupaten Tapanuli Tengah, Kota Sibolga, dan Kabupaten Toba Samosir; kedua, fase penggalangan dukungan (2006), yaitu fase dimana penggalangan terhadap daerah lainnya sebagai daerah tambahan yang disebabkan oleh adanya perubahan jumlah syarat minimum kabupaten/kota dalam pembentukan provinsi (akibat perubahan atas UU No. 22 Tahun 1999 tentang Pemerintahan Daerah menjadi UU No. 32 Tahun 2004, dari minimum 3 (tiga) kabupaten/kota menjadi 5 (lima) kabupaten/kota). Ada 3 (tiga) daerah yang memberikan dukungan tambahan, antara lain: Kabupaten Humbang Hasundutan, Kabupaten Samosir, dan Kabupaten Nias Selatan.

Hingga tahun 2008, proses konsolidasi antarkabupaten/kota yang mengusung pembentukan Provinsi Tapanuli tidak solid lagi. Ini bisa dilihat dari keputusan bupati/walikota dan keputusan DPRD kabupaten/kota perihal cakupan wilayah, penetapan nama, penetapan lokasi ibukota, alokasi dana, penyerahan aset, dan pemindahan personil pembentukan calon Provinsi Tapanuli - yang hanya diterbitkan oleh 6 (enam) kabupaten/kota. Hal ini disebabkan oleh Keputusan DPRD Kabupaten Tapanuli Tengah yang secara resmi mencabut dukungan terhadap pembentukan Provinsi Tapanuli pada tanggal 21 Nopember 2008. Penarikan dukungan tersebut dilatarbelakangi oleh persetujuan Kabupaten Tapanuli Tengah dalam pembentukan Provinsi Tapanuli Barat.

Ketiga, fase finalisasi, yaitu fase dimana upaya pembentukan Provinsi Tapanuli telah mencapai tahapan akhir, yang ditandai dengan diterbitkannya surat presiden RI Nomor R.04/Pres/02/2008 tentang Pembentukan Kabupaten/Kota dan Pembentukan Provinsi Tapanuli - yang merupakan amanat presiden kepada Dewan Perwakilan Rakyat (DPR) untuk membahas Rancangan Undang-Undang pembentukan 14 kabupaten/kota dan Provinsi Tapanuli - dan Keputusan Gubernur Sumatera Utara tentang Persetujuan Pembentukan Provinsi Tapanuli dan Cakupan Wilayah Kabupaten /Kota Calon Provinsi Tapanuli.

Keempat, fase kehancuran (patahan sejarah), yaitu fase dimana proses yang selama ini telah ditempuh dalam pembentukan Provinsi Tapanuli, akhirnya hancur dan justru menimbulkan trauma politik bagi masyarakat akibat sikap anarkisme gerakan kelompok pendukung Provinsi Tapanuli yang dikaitkan dengan kematian mendadak Abdul Azis Angkat (Ketua DPRD Sumatera Utara) saat Rapat Paripurna DPRD Sumatera Utara (tanggal 3 Februari 2009). Selain itu, tokoh-tokoh yang menjadi penggerak pembentukan Provinsi Tapanuli yang tersangkut masalah hukum juga turut menambah catatan hitam perjalanan politik pemekaran daerah di Sumatera Utara.

Fase-fase yang telah dipaparkan diatas merupakan kompleksitas masalah yang terjadi dalam sejarah politik pemekaran di Sumatera Utara, khususnya kebijakan di seputar pembentukan Provinsi Tapanuli, sepanjang proses pencapaiannya tidak elegan, elitis, dan kental nuansa politik kepentingan antardaerah. 


\section{Instrumen Pembangunan}

Di tengah kebijakan moratorium pemekaran yang didengungkan oleh Pemerintah Pusat, namun pemekaran daerah - sebagai amanat UU No. 32 Tahun 2004 - tidak serta merta terhambat oleh kebijakan yang tidak populis itu. Kebijakan tersebut justru kontraproduktif dengan upaya percepatan pembangunan di seluruh wilayah Republik Indonesia. Sinergisitas pelaksanaan program pembangunan yang dimandatkan oleh pusat terhadap daerah tidak akan berjalan jika aspirasi dan prakarsa masyarakat tidak mendapat tempatnya dalam upaya pemekaran daerah.

Sebagai contoh, beberapa daerah (Kabupaten Tapanuli Tengah, Kabupaten Tapanuli Utara, Kabupaten Tapanuli Selatan, dan Kabupaten Madina) yang berada di posisi Pantai Barat Sumatera Utara mengalami kesulitan dalam porsi anggaran dari tingkat provinsi karena masih ada anggapan bahwa wilayah Pantai Barat Sumatera Utara merupakan halaman belakang Provinsi Sumatera Utara. Jadi dengan demikian, prasyarat yang dibutuhkan untuk mendorong kemajuan suatu daerah tidak berjalan, misalnya kondisi jalan provinsi dan jalan kabupaten/kota yang rusak parah di Kawasan Pantai Barat Sumatera Utara.

Untuk itu, jika pemekaran dijadikan sebagai salah satu instrumen pembangunan daerah dalam rangka percepatan pembangunan, maka setiap daerah pemekaran baru dapat berkreasi sesuai dengan potensi alam, sumber daya manusia, dan kemampuan anggaran yang dimiliki. Hal ini dapat menjadi tenaga pendorong pemajuan suatu daerah untuk tujuan mendukung kepentingan pembangunan nasional. Pemekaran bukanlah jalan satu-satunya dalam tujuan mencapai kemakmuran daerah, tapi tanpa hak otonom bagi daerah dalam pengelolaan rumah tangganya, maka jebakan kemiskinan tetap menjadi warisan bagi masa depan anak bangsa. $* * *$

\footnotetext{
*Tulisan ini pernah dimuat di Harian ANALISA (Edisi Cetak), Senin, 20 Juni 2011, dan dimuat juga di URL:
}

(http://www.analisadaily.com/index.php?option=com content\&view=article\&id=99021:perlukahsumut-dimekarkan\&catid=78:umum\&ltemid=131) 